\title{
Does gender influence food intake and physical activity pattern among Palestinian adolescents in the Gaza Strip?
}

Amal Sarsour, ${ }^{1,2}$ Maysoun Turban, ${ }^{1}$ Adnan Al Wahaidi, ${ }^{1}$ Yehia Abed ${ }^{2}$ and Hesham Alkahlout ${ }^{1}$

ㅅArd El Insan Palestinian Benevolent Association, Gaza, Palestine (Correspondence to Amal K. Sarsour: amal_env@yahoo.com).

\begin{abstract}
Background: One of the most important parameters that affect the development of adolescents is nutrition. Eating practices among adolescents may have long-term impact on their health,

Aims: This study aimed to assess whether there is a difference in food intake and physical activity patterns among male and female adolescents (12-19 years old) in the Gaza Strip.

Methods: The cross-sectional study was conducted in April 2016 among 378 adolescent students, 205 males, 173 females. Researchers utilized quantitative and qualitative measures by incorporating a face-to-face interview questionnaire with the adolescents and focus group discussions with parents.

Results: Over $55 \%$ of participants were eating healthy foods with high frequency; the proportion of boys was greater than that of girls $(P<0.05)$. Around $45 \%$ were eating unhealthy foods with high frequency; here the proportion of girls was greater, but the difference was not statistically significant $(P>0.05)$. In terms of physical activity pattern, more than half of the adolescents were practicing a sedentary lifestyle, girls statistically significantly more than boys $(P<0.001)$. No statistically significant sex-based association was found between food intake habits and physical activity pattern.
\end{abstract}

Conclusions: Palestinian adolescents of both sexes in the Gaza Strip are practising unhealthy feeding habits coupled with an apparently highly sedentary lifestyle.

Keywords: lifestyle, adolescents, eating practices, physical activity, Gaza Strip

Citation: Sarsour A; Turban M; Al Wahaidi A; Abed Y; Alkahlout H. Does gender influence food intake and physical activity pattern among Palestinian adolescents in the Gaza Strip? East Mediterr Health J. 2019;25(10):722-727. https://doi.org/10.26719/emhj.19.073

Received: 17/05/17; accepted: 08/01/18

Copyright $@$ C World Health Organization (WHO) 2019. Some rights reserved. This work is available under the CC BY-NC-SA 3.0 IGO license https:// creativecommons.org/licenses/by-nc-sa/3.o/igo

\section{Introduction}

One of the most important parameters affecting the development of adolescents is nutrition: there is an increased need for energy and nutrients to support the increased rate of growth and development $(1-3)$. Previous research shows that eating practices among adolescents may have a long-term impact on their health, habits developed during this period may affect the health of the individual throughout their life (4-7). Accordingly, if adolescents are well nourished, they can make optimal use of their skills, energies and talents today, and be responsible parents of healthy babies in the future $(8,9)$.

Nutritional requirements vary during the growing years and should be adequate and match the energy and nutritional requirements associated with physical activity (10-12). Undertaking physical activity in adolescence is beneficial for health, and can set standards for adult physical activity levels, thereby influencing health outcomes in later life. Traditionally, daily active play and physical activity have been an important part of life for children and adolescents. Today, computers and social media have reduced the need and desire among children to move and play. Participation in physical activity decreases with age, and the decline is greater in girls than boys. The challenges associated with getting kids active every day should be met with age-appropriate physical activities, enthusiastic leadership, and support from family and friends (10).
Research supports the role that physical activity in adolescence has in the prevention and treatment of a range of health issues (12-14), and contributes to a healthier status and better physical and psychological well-being during these years and also later in life $(10,15)$.

Globally, $81 \%$ of adolescents aged 11-17 years were insufficiently physically active; adolescent girls were less active than boys, with $84 \%$ versus $78 \%$ respectively not meeting WHO recommendations (16). Locally, a crosssectional study was performed on early adolescents in preparatory schools. The r esults showed that about $49 \%$ of the females exhibited a sedentary lifestyle whereas $55 \%$ of the males practised an active or very active lifestyle. Females consumed less of certain food items (meat, eggs, milk) than males (17).

The Palestinian Health Behaviour in School-Aged Children is a cross-sectional survey of grades $6,8,10$ and 12. Students completed a modified version of the international Health Behaviour in School-Aged Children questionnaire. A total of 8885 students from the West Bank and the Gaza Strip were included in this analysis. The main results emphasized that adolescents in the West Bank consumed more fruit, meat, chicken, sweets and soft drinks, but less vegetables than adolescents in Gaza $(P<0.01)$. Girls reported more daily consumption of fruit, vegetables and sweets than boys $(P<0.001)$, and less consumption of soft drinks, milk, meat and chicken $(P<0.01)$. Boys were physically more active than girls 
$(P<0.01)$. The results indicated that there are problems with Palestinian adolescents' eating, dieting and physical activity (18).

Physical inactivity is increasing and is widely recognized as a major risk factor for chronic diseases such as obesity $(14,19)$. Palestinian society is comparatively young: adolescents (age range 10-19 years) constitute $23.6 \%$ of the total population (20). Despite the fact that adolescents are considered the future of any country, the situation in Gaza is not promising regarding opportunities for the new generation to create another history (21). In general, physical activity is not common among Palestinians in the Gaza Strip. This may be due to lack of public areas for practising physical activity, the negative effects of the unstable political situation on the behaviour of the community or low awareness of the community in regard to the importance and the benefits of physical activity for health (17).

This study aims to assess whether gender in fluences food intake and physical activity patterns among adolescents (12-19 years) in the Gaza Strip.

\section{Methods}

\section{Study design, setting and sample}

This cross-sectional study was conducted in April 2017 to identify and assess food intake and physical activity patterns of adolescents in the Gaza Strip. The sample frame was all adolescents aged 12-19 years who were enrolled in the schools in the Gaza Strip (governmental and private) during the academic year 2015-2016, amounting to 204888 (governmental $=232$ 186, private $=16$ 637). Using EpiInfo indicated that at $95 \%$ confidence intervals with proportion $30 \%$ of the estimated problem, and with worst estimate (35\%), sample size was 323 individuals. This was increased to 400 to compensate for nonrespondents. Participants were selected according to the number of students in each school, and size was selected considering the total number of government and private schools in each area. Accordingly, out of the 392 governmental and 56 private schools, 265 students (boys and girls) were selected from 12 government schools, and 135 from 6 private schools, with total sample size of 378 .

The investigation was carried out in accordance with the latest version of the Declaration of Helsinki and informed consent was obtained from the participants' parents after the nature of the procedures had been fully explained. Official approval for the study was obtained from the Ministry of Education and Higher Education. Every participant in the study received a complete explanation about the research purposes and the confidentiality of the information collected.

Questionnaires were administered in face-to-face interviews was carried out by trained research assistants inside the selected schools during class time. Each interview lasted on average 20-25 minutes. Two focus group discussions were also conducted with parents in an attempt to obtain deep answers and clarifications about the adolescents' food intake habits and physical activity patterns. Each discussion lasted on average 120 minutes, and had 10-12 participants with various characteristics to ensure they represented parents of students from government schools, UNRWA schools, and private schools and from different socioeconomic conditions. The study population comprised 378 adolescents (205 boys, 173 girls) aged 12-19 years, mean age 14.85 [standard deviation (SD) 1.52] years. The response rate was (94.5\%). All students were selected systematically from the students register in each school.

\section{Questionnaire}

The questionnaire was adapted from a number of different sources (3,22-24), and covers diverse issues/themes about food intake, and physical activity.

\section{Food intake}

Food intake was assessed using a food frequency questionnaire (20 indicator variables) that measured consumption of milk, eggs, beverages, sweets, cake/cookies, Chinese noodles (endomy), chips, fast food, canned food, pickles, junk and/or spicy foods, roasted food (shawerma), fried foods and oil, dried fruits, cooked vegetables, lemonade and or soft drinks, meat/sausage products, chicken, fish/sea food, dairy products and cereals.

The instrument was created to include food categories such as healthy and unhealthy foods that are important when studying dietary habits. The introductory question, "How often do you eat the following foods?" was asked of students about the frequency of their usual consumption of each food group separately (rated on a 5-point scale: several times a day, daily, several times a week, 1-2 times a month and never) (24). The scale for healthy food was recategorized into 3 scales: high intake, low intake and never. Mean differences in relation to sex were measured according to this scale.

\section{Physical activity pattern}

The participants were asked how often they practised a specific leisure activity and for how long on each occasion. The response categories were sorted as: daily, weekly and minutes on each occasion. All times spent in each specific daily physical activity over 24 hours were summed. This was multiplied by a specific factor for each physical activity. The net result was added to 1.1 (to account for basal energy and the thermic effect of food) in order to give a score which indicates the person's physical activity level according to age and sex (3). According to this score, the physical activity was classified into sedentary (1.0-1.39), low active (1.4-1.59), active (1.6-1.89) and very active $(\geq 1.9)$.

\section{Statistical analysis}

Data were analysed using SPSS, version 24. Mean, SD and cross tabulation of the results were used to demonstrate the study items. Appropriate advanced statistical analysis was conducted in order to explore the potential relationship between variables. Therefore, independent 
t-test and chi-squared were used to investigate the relationship between the study variables. Statistical significance was set at $P<0.05$.

\section{Results}

\section{Demographic information:}

The study sample comprised $54.2 \%$ males and $45.8 \%$ females. Most (58.7\%) were in the age group 14-17 years, $40.3 \%$ were aged $12-14$ years and only $0.8 \%$ were aged $17+$ years. About $53 \%$ of participants were in preparatory school, the rest were secondary school students.

\section{Food intake}

Food intake items were recategorized into healthy and unhealthy $(3,24)$. The frequency of each category was summed and divided into low and high. We found that $56.3 \%$ of adolescents were eating healthy foods with high frequency, with boys (57.1\%) exceeding girls (55.5\%) slightly (Table 1). However, the mean score for girls (1.69, SD 0.33) was higher than the mean for boys (1.57, SD 0.24) and the difference was statistically significant $(P<0.05)$ (Table 2).

On the other hand, $45.5 \%$ of the adolescents were eating unhealthy foods with high frequency, with a greater proportion of females (46.8\%) than males (44.4\%) but the difference was not statistically significant $(P>0.05)$. Indeed, there was no statistically significant difference in food intake between the sexes.

\section{Physical activity pattern}

As illustrated in Table 3, more than half the adolescents in our study were living a sedentary life, with more girls (85.5\%) than boys $(34.1 \%)$ doing so. While $29.9 \%$ of adolescents overall were classed as active, only $6.4 \%$ of girls were in this category. All times spent on each specific daily physical activity over 24 hours were summed. Results of the t-test show a strong statistically significant difference between males and females in practising physical activity: mean number of minutes/day was 58.0 (SD 29.8) for boys and 68.2 (SD 48.7) for girls (t-test 2.496; $P<0.013)$.

\section{Differences in food intake and physical activity}

No statistically significant sex-based association was found between food intake habits and physical activity pattern among the adolescents in our study.

\begin{tabular}{|c|c|c|c|}
\hline $\begin{array}{l}\text { Intake category } \\
\& \text { frequency }\end{array}$ & $\begin{array}{c}\text { Males } \\
(n-205) \\
(\%)\end{array}$ & $\begin{array}{c}\text { Females } \\
(n-173) \\
(\%)\end{array}$ & $\begin{array}{c}\text { Total } \\
(n-378) \\
(\%)\end{array}$ \\
\hline \multicolumn{4}{|l|}{ Healthy } \\
\hline Low & 42.9 & 44.5 & 43.7 \\
\hline High & 57.1 & 55.5 & 56.3 \\
\hline \multicolumn{4}{|l|}{ Unhealthy } \\
\hline Low & 55.6 & 53.2 & 54.5 \\
\hline High & 44.4 & 46.8 & 45.5 \\
\hline
\end{tabular}

Table 2 Healthy food intake among male and female adolescents in the Gaza Strip

\begin{tabular}{lcccc} 
Sex & $\begin{array}{c}\text { Mean } \\
\text { score }\end{array}$ & SD & t-test & $P$ \\
Male $(n=205)$ & 1.57 & 0.24 & \multirow{2}{*}{4.035} & $<0.001$ \\
Female $(n=173)$ & 1.69 & 0.33 & & \\
\hline$S D=$ standard deviation. & & & &
\end{tabular}

Generally, most of the parents in the focus group discussions asserted that their adolescents know what food is healthy, its content and importance, yet, they don't pay attention to this. Parents play a major role in their children's food intake by trying to consider healthy food and avoiding foods which lead to obesity.

"I can't force them to eat everything but I try to convince them, we agreed together on what they want to eat from the healthy food." (mother of an adolescent)

"My boy's health is affected negatively due to his bad nutritional behaviour and unhealthy food intake, he is very obese, while my daughter is very thin." (father of an adolescent)

In terms of physical activity, most of the parents in the focus groups said that their adolescents practice physical activity, whereas they confirmed that boys are interested in physical activities more than girls, and this is consistent with the answers of the adolescents in the present study.

"Obesity is prohibited at home, and then controlling food intake and doing physical activities is considered one of the main issues". (mother of an adolescent)

Table 3 Healthy food intake among male and female adolescents in the Gaza Strip

\begin{tabular}{lccccccc} 
Category & \multicolumn{2}{c}{ Males } & \multicolumn{2}{c}{ Females } & \multicolumn{2}{c}{ Total } \\
& No. & $\%$ & No. & $\%$ & No. & \% \\
\hline Sedentary & 70 & 34.1 & 148 & 85.5 & 218 & 57.7 \\
Low active & 33 & 16.1 & 14 & 8.1 & 47 & 12.4 \\
Active & 102 & 49.8 & 11 & 6.4 & 110 & 29.9 \\
Total & $\mathbf{2 0 5}$ & $\mathbf{1 0 0 . 0}$ & $\mathbf{1 7 3}$ & $\mathbf{1 0 0 . 0}$ & $\mathbf{3 7 8}$ & $\mathbf{1 0 0 . 0}$ \\
\hline
\end{tabular}


"Boys are interested in physical activities more than girls, girls go to gym only to preserve their general appearance or are affected by their peers." (mother of an adolescent)

\section{Discussion}

The main findings of this study emphasized that more than half the adolescents were eating healthy foods with high frequency although the parents complained that their children did not generally eat healthily. In terms of physical activity, a less healthy pattern was evident, with more than half of the participants $(57.7 \%)$ practising a sedentary lifestyle, particularly girls (85.5\%).

Our results did not agree with the findings of some previous research conducted on Palestinian adolescents with regard to food habits and physical activity which found that girls were more likely to report healthier food choices, with a higher consumption of fruits and vegetables $(18,25)$. However, the trend among girls is to practise a more sedentary lifestyle. This can be an attributed to cultural trends of the Gaza Strip where girls actually stay at home once they reach 12 years old and hence, no more outdoor physical activity is accessible, unlike boys (17). Moreover, these results are similar to the results of the Palestinian micronutrient survey which reported that $52.2 \%$ of adolescent girls did not exercise regularly outside school hours compared with $21.7 \%$ of the boys; $51.6 \%$ of the adolescent boys exercised $1-3$ hrs per day (25).

Form another aspect, our findings are more positive than the findings of 2 previous local studies which revealed that more than one third of students practised a sedentary lifestyle $(17,26)$. Globally, $81 \%$ of adolescents aged (11-17 years) were insufficiently physically active, where adolescent girls were less active than adolescent boys, $84 \%$ versus $78 \%$ respectively not meeting WHO recommendations (16).

Another study indicates that increasing sedentary behaviour contributes to the development of obesity in adolescent girls, and research on interventions designed to decrease sedentary time in this population are warranted (27). These could be justified since all the conveniences of our modern lifestyle have made us sedentary, sitting in front of the TV or the computer, using a car for even short trips and using elevators instead of stairs all contribute to our inactivity. Physical inactivity has been described as being as dangerous to our health as smoking (17).

\section{Conclusion}

In terms of food intake, a high percentage of adolescents consume unhealthy foods, reflecting an overwhelming social trait. Differences of physical activity patterns between males and females may be explained by the fact that boys practice more physical activity outside their homes freely but girls are deprived of this due to cultural factors. Our findings indicate that Palestinian adolescents in both sexes in the Gaza Strip are practising unhealthy food habits coupled with an apparently highly sedentary lifestyle. Such a matter requires greater interest at all levels of the community and among decision-makers.

Funding: Ibhath research grant, Qatar Charity, completed by Ard El Insan Association.

Competing interests: None declared.

\section{Influence de l'appartenance sexuelle sur les modes de consommation alimentaire et d'activité physique chez les adolescents palestiniens de la bande de Gaza Résumé}

Contexte : La nutrition est l'un des paramètres les plus importants qui affectent le développement des adolescents. Les pratiques alimentaires des adolescents peuvent avoir un impact sur leur santé à long terme.

Objectif : La présente étude visait à déterminer s'il y avait une différence dans les modes de consommation alimentaire et d'activité physique chez les adolescents et les adolescentes (âgés entre 12 et 19 ans) de la bande de Gaza.

Méthodes : L'étude transversale a été menée en avril 2016 auprès de 378 étudiants adolescents (205 garçons et 173 filles). Les chercheurs ont utilisé des mesures quantitatives et qualitatives en incorporant un questionnaire d'entretien en présentiel avec les adolescents et des discussions de groupe avec les parents.

Résultats : Plus de $55 \%$ des participants consommaient des aliments sains à une fréquence élevée ; la proportion de garçons était supérieure à celle des filles $(p<0,05)$. Environ $45 \%$ consommaient fréquemment des aliments malsains ; à cet égard, la proportion de filles était plus élevée, mais la différence n'était pas statistiquement significative ( $p>0,05)$. En termes de mode d'activité physique, plus de la moitié des adolescents avaient un mode de vie sédentaire, les filles étant statistiquement beaucoup plus nombreuses que les garçons $(p<0,001)$. Aucune association significative basée sur le sexe n'a été trouvée entre les habitudes alimentaires et le mode d'activité physique.

Conclusions : Les adolescents palestiniens des deux sexes dans la bande de Gaza ont des habitudes alimentaires malsaines, associées à un mode de vie apparemment très sédentaire. 


$$
\text { تأثير اختلاف المنس صرص صور، ميسون تربان، عدنان الوحناول الطعام ونمط النشاط البدني في أوساط المر اهقين الفلسطينين بقطاع غزة هشام الكحلوت }
$$

$$
\begin{aligned}
& \text { الخلفية: التغذية من أهم المتثثابتات التي تؤثر في تطور المراهقين. وقد يكون لممارسات المراهقين الغذائية تأثير بعيد المدى على صحتهم. } \\
& \text { الأهداف: تهدف هذه الدراسة إلى تحديد ما إذا كان هناك اختلاف في أنماط تناول الطعام والنشاط البدني بين المراهقين (من با إلى } 19 \text { سنة) من } \\
& \text { الذكور والإناث في قطاع غزة. }
\end{aligned}
$$

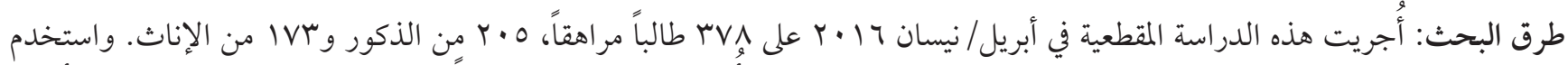

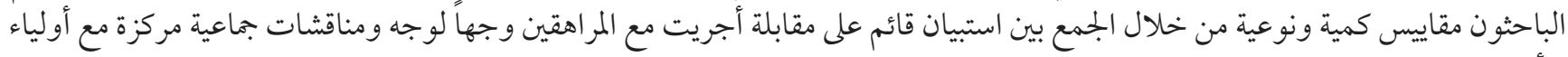

$$
\begin{aligned}
& \text { الأمور. }
\end{aligned}
$$

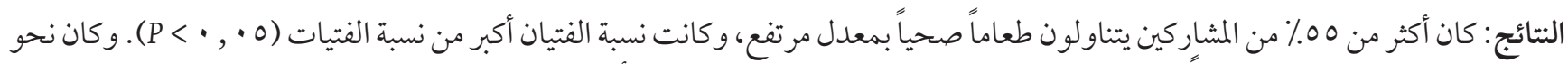

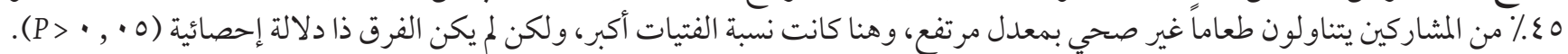

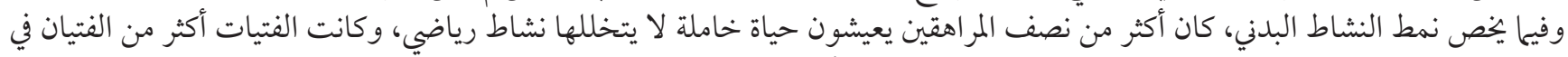

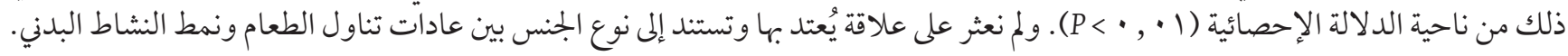
الاستنتاجات: يمارس المراهقون الفلسطينيون من كلا الجنسين في قطاع غزة عادات غذائية غير صحية إلى جانب أنهم يعيشون حياة تبدو خاملة

\section{References}

1. Fink H, Burgoon L, Mikesky A. Practical applications in sports nutrition, 4th ed. Boston: Jones and Bartlett; 2006.

2. Mahan L, Escott-Stump S. Krause's food, nutrition, and diet therapy, 11th ed. Philadelphia: Saunders; 2004.

3. Rolfes R, Pinna K, Whitney E. Understanding normal and clinical nutrition, 7th ed. Belmont, California: Thomson/Wadsworth; 2006, Ch. 13:438-47.

4. Erturgut P, Erturgut R. An analysis of nutrition level of adolescent school children with respect to the educational levels and child-raising attitudes of their parents. Procedia Soc Behav Sci. 2010;2(2):1238-43. https://doi.org/10.1016/j.sbspro.2010.03.180

5. Stang J, Story MT, eds. Guidelines for adolescent nutrition services. Minneapolis: Center for Leadership, Education and Training in Maternal and Child Nutrition; 2005.

6. Croll J, Neumark-Sztainer D, Story M. Healthy eating: What does it mean to adolescents? J Nutrition Education, 2001;33(4):93198. PMID:11953240

7. Hammons A, Fiese B. Is frequency of shared family meals related to the nutritional health of children and adolescents? J Am Academy Pediatrics. 2011;127(6):1-10. doi:10.1542/peds.2010-1440

8. Bhabha J. Adolescents: current rights for future opportunities. In south-south cooperation for child rights working paper 2. Kathmandu: UNICEF; 2013 (http://www.unicef.org/eapro/Working_paper_2, accessed 21 April 2019).

9. Improvement of nutritional status of adolescents. Report of the Regional Meeting, Chandigarh, India 17-19 September 2002. New Delhi: World Health Organization Regional Office for South-East Asia; 2002.

10. Faigenbaum D. Physical activity in children and adolescents. American College of Sports Medicine Bulletin. 2015 January (https://www.researchgate.net/publication/296848150_Physical_Activity_in_Children_and_Adolescents, accessed 21 April 2019).

11. Benardot D. Advanced sports nutrition, 2nd edn. Champaign, Illinois: Human Kinetics; 2006.

12. OECD/EU. "Physical Activity among Children", in Health at a Glance: Europe. Paris: OECD Publishing; 2010. doi:http://dx.doi. org/10.1787/9789264090316-23-en

13. Physical Activity Guidelines Advisory Committee Report. Washington, DC: Department of Health and Human Services: 2008.

14. Aznar-Lain S, Webster T. Physical activity and health in children and adolescents: A guide for all adults involved in educating young people. Ministerio de Educación y Ciencia / Ministério de Sanidad y Consumo; 2007.

15. Martín-Matillas M, Ortega F, Ruiz J, Martínez-Gómez D, Marcos A, Moliner-Urdiales D, et al. Adolescent's physical activity levels and relatives' physical activity engagement and encouragement: the HELENA study. Eur J Public Health. 2011;21(6):705-12. doi:10.1093/eurpub/ckq143

16. Physical activity Fact Sheet WHO, N 385 Updated. Geneva: World Health Organization; 2015 (http://www.who.int/mediacentre/ factsheets/fs385/en/, accessed 21 April 2019).

17. Abu Nada O. Nutritional Assessment of zinc and iron among early adolescents in preparatory schools in Gaza Strip [thesis].

Gaza: College of Pharmacy, Al Azhar University-Gaza; 2010. 
18. Al Sabbah H, Vereecken C, Kolsteren P, Abdeen Z, Maes L. Food habits and physical activity patterns among Palestinian adolescents: findings from the national study of Palestinian schoolchildren. Public Health Nutr. 2007; 10(7):739-46. doi:10.1017/ S1368980007665501

19. Micklesfield L, Pedro T, Kahn K, Kinsman J, Pettifor JM, Tollman S, et al. Physical activity and sedentary behavior among adolescents in rural South Africa: levels, patterns and correlates Micklesfield et al. BMC Public Health. 2014; 14:40. http://www. biomedcentral.com/1471-2458/14/40

20. [Health annual report 2013]. Palestinian Health Information Centre, Ministry of Health; 2014 http://www.moh. ps/?lang=1\&page=4\&id=20\#, accessed 21 April 2019) (in Arabic).

21. Singh A, Qren K. Gaza strip: healthy adolescence - a distant dream. An enquiry into food security with relation to growth of adolescents' contents. Oslo: Faculty of Social Science Oslo and Akershus University College of Applied Sciences; 2011 (http://www. academia.edu/6446986/Gaza_Strip_Healthy_Adolescence, accessed 21 April 2019).

22. WHOQOL-HIV Instrument. Geneva: World Health Organization, Mental Health: Evidence and Research Department of Mental Health and Substance Dependence; 2012 (WHO/MSD/MER/Rev).

23. CDC HRQOL-14 "Healthy Days Measure". Atlanta: Centers for Disease Control and Prevention, 2012 (http://www.cdc.gov/ hrQoL/hrQoL14_measure.htm\#1, accessed 21 April 2019).

24. Yassin M, Sarsour A, Alharazin H. Food consumption in association with perceived stress and depressive symptoms: a cross sectional study from five universities and three collages in Gaza Strip, Palestine. Eur J Preventive Medicine. 2016; 4 (1):20-7. doi:10.11648/j.ejpm.20160401.14

25. Elmadfa, I, Abu Rub, A, Ben-Abdullah, K Elmadfa A, Abu-Rub A, Meyer AL, Ramlawi A, Bahar L, Rizkallah N, et al. Palestinian micronutrient survey (PMS). Final report. Ramallah: Ministry of Health, Primary Health Care \& Public Health; 2014.

26. Jalambo M, Hamad A, Abed Y. Anemia and risk factors among female secondary students in the Gaza Strip. Public Health, 2013;2:271. doi:10.1007/s10389-012-0540-9

27. Micklesfield LK, Pedro TM, Kahn K, Kinsman J, Pettifor JM, Tollman S, et al. Physical activity and sedentary behaviour among adolescents in rural South Africa: levels, patterns and correlates. BMC Public Health, 2014;14:40. https://doi.org/10.1186/1471-2458$14-40$. 